\title{
Apolipoprotein B Signal Peptide Polymorphism: Distribution and Influence on Lipid Parameters in Tunisian Population
}

\author{
A. KALLEL, M. FEKI, M. ELASMI, M. SOUISSI, H. SANHAJI, S. OMAR, \\ S. HAJ TAIEB, R. JEMAA, N. KAABACHI
}

Laboratoire de Recherche LAB-SM-01, Service de Biochimie, Hôpital la Rabta, Tunis, Tunisia

Received May 5, 2006

Accepted July 18, 2006

On-line available August 22, 2006

\begin{abstract}
Summary
Apolipoprotein B (apo B) is the major protein component of LDL, VLDL and chylomicrons. Numerous polymorphisms of the apolipoprotein B gene have been described. Particularly, the insertion/deletion polymorphism located in the coding part of the signal peptide of apo B, associated with modification of lipid concentrations and the risk of cardiovascular disease, has been reported in the general population. No such study in the Tunisian population has been performed. The aim of our study was to assess the effect of insertion/deletion polymorphism of the apolipoprotein B gene on lipid levels in a sample of the Tunisian population. A total of 458 unrelated subjects (321 men and 137 women) were included. The insertion/deletion polymorphism was determined by electrophoresis on polyacrylamide gels after PCR amplification. The relative frequencies of the Ins and Del alleles were 0.74 and 0.26 , respectively. These frequencies were similar to those found in other Caucasian populations. There was no significant difference in serum $\mathrm{TC}$, TG, and HDL-C levels due to the influence of the genotypes. However, significant variation among the three genotypes was seen for LDL-cholesterol $(\mathrm{p}<0.001)$ and apo $\mathrm{B}(\mathrm{p}<0.001)$ levels. Individuals homozygous for the Del allele had higher levels than individuals homozygous for the Ins allele, while individuals heterozygous for both alleles exhibited intermediate levels. When the data were analyzed in men and women separately, a similar effect was seen in both groups. Our results show that distribution of apo B insertion/deletion polymorphism in Tunisians is similar to other Caucasian population and confirm the reported association with serum LDL-cholesterol and apo B concentrations.
\end{abstract}

\section{Key words}

Lipids $\bullet$ Apo B gene $\bullet$ Polymorphism $\bullet$ Signal peptide

\section{Introduction}

Epidemiological studies have identified plasma lipid levels as one of the risk factors for development of atherosclerosis (Avogaro et al. 1979). As a major protein in chylomicrons, very low density lipoprotein (VLDL), intermediate density lipoprotein (IDL) and low density lipoprotein (LDL) particles, apolipoprotein B (apo B), is a ligand for the LDL receptor mediating internalization of LDL particles (Brown and Goldstein 1986). It is also important in the assembly and secretion of chylomicrons from the intestine and VLDL from the liver (Oloffson et al. 1987). Because of its central role in lipid transport and metabolism, the examination of the variations of the apo B gene could help to explain interindividual variation in lipid levels and susceptibility to coronary heart disease. 
The gene coding for human apo B is $43 \mathrm{~kb}$ in length with 81 bp coding for a 27 -amino acid signal peptide. This terminal signal sequence directs the emerging protein to translocate through the endoplasmic reticulum membrane. The polymorphism of signal peptide was first typed directly using the polymerase chain reaction (PCR) by Boerwinkle and Chan (1989). A significant association was detected between the insertion/deletion polymorphism and plasma glucose levels in Europeans and Mexican Americans (Boerwinkle et al. 1991). Some studies have also demonstrated associations between the insertion/deletion polymorphism and lipid levels (Hansen et al. 1993, Choong et al. 1999, Boekholdt et al. 2003, Jemaa et al. 2004a,b). Anderson et al. (1997) indicated that apo B polymorphism affects interindividual variation in serum lipoprotein and lipid levels in African populations. Besides the insertion and deletion alleles, a 99-bp rare allele was detected in African blacks (Anderson et al. 1997), Caucasians (Hixson et al. 1992), and Mexican Americans (Boerwinkle et al. 1990). This allele contains a 29 -amino acid signal peptide as a result of the addition of two leucines in a region that normally has six identical codons for leucine (Hixson et al. 1992).

Although the apo B signal peptide polymorphism has been extensively studied in different populations, there is no information about its distribution in the Tunisian population. In this study, we report the allele frequency of this polymorphism in a sample of healthy Tunisians and examine the influence of this polymorphism on serum lipid and apolipoprotein concentrations.

\section{Materials and Methods}

\section{Subjects}

A total of 458 unrelated healthy subjects (321 men and 137 women) without a past record of clinical coronary manifestations, were recruited. The average age of the subjects was 51.6 years (range 32-65 years) and was similar for males and females (52.2 and 50.3 years, respectively). All subjects gave their informed consent and the protocol was approved by the Rabta Hospital Ethics Committee.

Weight and height were measured on the subjects barefooted and lightly clothed. Body mass index (BMI, $\mathrm{kg} / \mathrm{m}^{2}$ ) was calculated and obesity was defined as BMI $\geq 30 \mathrm{~kg} / \mathrm{m}^{2}$. Diabetes was defined as a fasting blood glucose level above $7 \mathrm{mmol} / \mathrm{l}$ or the use of antidiabetic drugs, or both. Hypertension was defined as systolic blood pressure $\geq 140 \mathrm{~mm} \mathrm{Hg}$ and/or diastolic blood pressure $\geq 90 \mathrm{~mm} \mathrm{Hg}$ or the use of antihypertensive drugs or both. Dyslipidemia was defined as a total cholesterol (TC) level above $6.47 \mathrm{mmol} / \mathrm{l}$ and/or triglyceride (TG) level above $2.26 \mathrm{mmol} / \mathrm{l}$.

\section{Lipid, lipoprotein and apolipoprotein measurements}

Blood samples were obtained after an overnight fast. Plasma levels of TC, TG and HDL-cholesterol (HDL-C) were measured by standardized enzymatic procedures, and apo AI and apo B were measured using turbidimetric assay on a Hitachi 912 analyzer. LDL cholesterol (LDL-C) was calculated according to formula of Friedwald et al. (1972).

\section{DNA analysis}

Genomic DNA was prepared from white blood cells by phenol extraction (Marcadet et al. 1987). Insertion/deletion polymorphism was analyzed after amplification of the corresponding region by the polymerase chain reaction (PCR) as described elsewhere (Jemaa et al. 2004a). The primers for PCR were obtained from QBiogene SA. The product gives to a 93-bp fragment corresponding to the insertion (Ins) allele or an 84-bp fragment corresponding to the deletion (Del) allele. The difference of $9 \mathrm{bp}$ corresponds to the presence or absence of three amino acids (Leu-Ala-Leu) in the signal peptide of the apo B.

\section{Statistical analysis}

Statistical analysis was performed using the SYSTAT statistical software, version 10. Differences among lipid and lipoprotein concentrations in different groups of individuals were compared using the Student's t-test normally distributed. The allele frequencies and genotype distribution were estimated by gene counting. Triglycerides were logarithmically transformed before the analysis to obtain the normal distribution. To evaluate the effect of polymorphism on the variation of lipid, one-way ANOVA was performed. A value of $p<0.05$ was considered statistically significant.

\section{Results}

Descriptive characteristics of all studied subjects are presented in Table 1. The mean age was 51.6 \pm 9.9 years. Men had a higher proportion of diabetes and smokers than women. The prevalence of hypertention, obesity and dyslipidemia were significantly higher in 
Table 1. Anthropometric and metabolic variables in the studied population

\begin{tabular}{lcccc}
\hline Variable & $\begin{array}{c}\text { Total population } \\
(\mathbf{n}=\mathbf{4 5 8})\end{array}$ & $\begin{array}{c}\text { Men } \\
(\mathbf{n}=\mathbf{3 2 1})\end{array}$ & $\begin{array}{c}\text { Women } \\
(\mathbf{n}=\mathbf{1 3 7})\end{array}$ & P \\
\hline Age $($ years) & $51.6 \pm 9.9$ & $52.2 \pm 9.6$ & $50.3 \pm 10.5$ & $\mathrm{NS}$ \\
BMI $\left(\mathrm{kg} / \mathrm{m}^{2}\right)$ & $27.4 \pm 6.4$ & $26.2 \pm 4.9$ & $30.4 \pm 8.4$ & $<0.001$ \\
Diabetes (\%) & 17.4 & 19.2 & 12.4 & $<0.05$ \\
HTA (\%) & 32.5 & 29.7 & 38.7 & $<0.05$ \\
Obesity (\%) & 27.5 & 21.1 & 43.1 & $<0.001$ \\
Dyslipidemia $(\%)$ & 18.4 & 15.8 & 24.8 & $<0.02$ \\
Smokers (\%) & 48.8 & 68.5 & 13.4 & $<0.001$ \\
TC $(\mathrm{mmol} / \mathrm{l})$ & $5.02 \pm 0.98$ & $4.92 \pm 37$ & $5.20 \pm 0.95$ & 0.004 \\
TG $(\mathrm{mmol} / \mathrm{l})$ & $1.51 \pm 0.85$ & $1.55 \pm 0.88$ & $1.41 \pm 0.79$ & $\mathrm{NS}$ \\
LDL-C $(\mathrm{mmol} / \mathrm{l})$ & $3.10 \pm 0.85$ & $3.03 \pm 0.82$ & $3.23 \pm 0.90$ & 0.03 \\
HDL-C $(\mathrm{mmol} / \mathrm{l})$ & $1.19 \pm 0.33$ & $1.13 \pm 0.25$ & $1.32 \pm 0.38$ & $<0.001$ \\
Apo B $(\mathrm{g} / \mathrm{l})$ & $0.96 \pm 0.24$ & $0.95 \pm 0.24$ & $0.97 \pm 0.25$ & $\mathrm{NS}$ \\
Apo AI $(\mathrm{g} / \mathrm{ll})$ & $1.36 \pm 0.29$ & $1.30 \pm 0.26$ & $1.48 \pm 0.32$ & $<0.001$ \\
\hline
\end{tabular}

Data are expressed as means \pm S.D.

women than in men. Serum levels of TC, LDL-C, HDL-C and apo AI were significantly higher in women than in men. No differences between men and women were observed for TG, and apo B.

The Del allele frequency in this population was 0.26 which is similar to the data from other Caucasian populations. The frequencies of Del allele were 0.30 in women and 0.24 in men. There was no significant difference in allele frequencies between the two samples. The distribution of all genotypes was in Hardy-Weinberg equilibrium.

Table 2 shows the influence of apoB signal peptide genotypes on serum lipids and apolipoproteins in the entire sample and by sex. There was no significant difference in serum TC, TG, and HDL-C levels according to genotypes. However, significant variation among the three genotypes was seen for LDL-cholesterol $(\mathrm{p}<0.001)$ and apo $B(p<0.001)$ levels. Individuals homozygous for the Del allele have higher levels than individuals homozygous for the Ins allele, while individuals heterozygous for both alleles have intermediate levels. When the data were analyzed in men and women separately, a similar effect was seen in both groups.

\section{Discussion}

The present study is the first that has examined the allelic frequencies and the effect of insertion/deletion polymorphism of the apo B gene in the Tunisian population.

The Del allele frequency observed in our population was 0.26. Similar values were observed in control groups by other investigators with Del allele frequencies of 0.297 (Finland) (Turner et al. 1995), 0.297 (UK) (Turner et al. 1995), 0.348 (Northern Europe), 0.333 (Central Europe) (Turner et al. 1995), 0.302 (Southern Europe) (Turner et al. 1995), 0.205 (American Africans) (Hixson et al. 1992), 0.335 (American Whites) (Hixson et al. 1992), 0.300 (Peacock et al. 1995), 0.310 (Marshall et al. 1994), 0.308 (Toulouse) (Visvikis et al. 1993), 0.293 (Strasbourg) (Visvikis et al. 1993) and 0.333 (Belfast) (Visvikis et al. 1993).

The apo B Ins/Del polymorphism has often been studied with regard to lipid levels and atherosclerosis. Most of the authors found Del allele to be associated with elevated total cholesterol and LDL-cholesterol levels in control samples. Our results in this population show an increase of the concentrations of LDL-cholesterol and apo B levels associated with the Del allele, which is in good agreement with most of the studies (Renges et al. 1991, Saha et al. 1992, 1993, Hubáček et al. 2001, Bohn et al. 1994, Kammerer et al. 1996, Gardemann et al. 1998) but not with all (Boekholdt et al. 2003, Gaffney et al. 1993, Gajra et al. 1994, Glisic et al. 1997). In our study, the carriers of Ins allele have lower LDLcholesterol and apo B concentrations, Ins/Del subjects 
Table 2. Comparison of variables between apoB peptide Ins/Del genotypes and by sex.

\begin{tabular}{|c|c|c|c|c|}
\hline Variables & Ins/Ins & Ins/Del & Del/Del & $\mathbf{P}$ \\
\hline Men and women & $\mathrm{n}=\mathbf{2 5 5}$ & $\mathrm{n}=171$ & $\mathrm{n}=32$ & \\
\hline Age (years) & $52.3 \pm 10.2$ & $50.9 \pm 9.7$ & $50.5 \pm 8.4$ & NS \\
\hline$T C(\mathrm{mmol} / \mathrm{l})$ & $5.02 \pm 0.98$ & $4.99 \pm 0.98$ & $4.99 \pm 0.93$ & NS \\
\hline$T G(\mathrm{mmol} / \mathrm{l})$ & $1.55 \pm 0.94$ & $1.44 \pm 0.75$ & $1.45 \pm 0.57$ & NS \\
\hline$L D L-C(\mathrm{mmol} / \mathrm{l})$ & $3.03 \pm 0.88$ & $3.10 \pm 0.80$ & $3.67 \pm 0.69$ & 0.001 \\
\hline$H D L-C(\mathrm{mmol} / \mathrm{l})$ & $1.19 \pm 0.36$ & $1.19 \pm 0.25$ & $1.21 \pm 0.25$ & NS \\
\hline Apo AI $(g / l)$ & $1.37 \pm 0.27$ & $1.33 \pm 0.32$ & $1.39 \pm 0.31$ & NS \\
\hline$A p o B(g / l)$ & $0.94 \pm 0.22$ & $0.96 \pm 0.24$ & $1.14 \pm 0.29$ & 0.001 \\
\hline Men & $n=184$ & $n=119$ & $n=16$ & \\
\hline Age (years) & $52.2 \pm 9.9$ & $52.0 \pm 9.4$ & $53.7 \pm 8.9$ & NS \\
\hline$T C(\mathrm{mmol} / \mathrm{l})$ & $4.45 \pm 1.06$ & $4.92 \pm 0.98$ & $4.94 \pm 0.95$ & NS \\
\hline$T G(\mathrm{mmol} / \mathrm{l})$ & $1.60 \pm 0.97$ & $1.50 \pm 0.77$ & $1.50 \pm 0.65$ & NS \\
\hline$L D L-C(\mathrm{mmol} / \mathrm{l})$ & $3.00 \pm 0.80$ & $3.05 \pm 0.80$ & $3.57 \pm 0.69$ & 0.04 \\
\hline$H D L-C(\mathrm{mmol} / \mathrm{l})$ & $1.13 \pm 0.31$ & $1.13 \pm 0.25$ & $1.16 \pm 0.25$ & NS \\
\hline Apo AI $(g / l)$ & $1.33 \pm 0.26$ & $1.26 \pm 0.27$ & $1.27 \pm 0.19$ & NS \\
\hline$A p o B(g / l)$ & $0.93 \pm 0.23$ & $0.97 \pm 0.22$ & $1.14 \pm 0.31$ & 0.003 \\
\hline Women & $n=69$ & $\mathrm{n}=\mathbf{5 2}$ & $\mathrm{n}=16$ & \\
\hline Age (years) & $52.5 \pm 11.2$ & $48.4 \pm 10.2$ & $47.3 \pm 6.6$ & NS \\
\hline TC $(\mathrm{mmol} / \mathrm{l})$ & $5.25 \pm 0.98$ & $5.07 \pm 0.93$ & $5.51 \pm 1.03$ & NS \\
\hline$T G(\mathrm{mmol} / \mathrm{l})$ & $1.43 \pm 0.90$ & $1.32 \pm 0.68$ & $1.62 \pm 0.48$ & NS \\
\hline$L D L-C(\mathrm{mmol} / \mathrm{l})$ & $3.15 \pm 0.98$ & $3.21 \pm 0.77$ & $3.78 \pm 0.69$ & 0.004 \\
\hline$H D L-C(\mathrm{mmol} / \mathrm{l})$ & $1.34 \pm 0.44$ & $1.32 \pm 0.33$ & $1.29 \pm 0.25$ & NS \\
\hline Apo $A I(g / l)$ & $1.47 \pm 0.29$ & $1.49 \pm 0.35$ & $1.49 \pm 0.32$ & NS \\
\hline$A p o B(g / l)$ & $0.95 \pm 0.22$ & $0.94 \pm 0.26$ & $1.14 \pm 0.28$ & 0.01 \\
\hline
\end{tabular}

Values are mean \pm S.D. TC, total cholesterol; TG, triglycerides; LDL-C, low-density lipoprotein; HDL-C, high-density lipoprotein; ApoAI, apolipoprotein AI; apoB , apolipoprotein B

have intermediate concentrations, and Del allele carriers have higher concentrations in both sexes. No association was found between Del allele and total cholesterol levels. In contrast to previous studies (Peacock et al. 1995, Visvikis et al. 1993, Bohn et al. 1994, Kammerer et al. 1996, Zaman et al. 1997, Hong et al. 1997) and to our present study, Xu et al. (1990) observed that the Del allele was associated with lower levels of serum triglycerides in a population of 106 Finnish individuals, whereas in French Whites but not Mexican Americans, the Del allele of the apo B Ins/Del gene variation was weakly associated with increased serum triglyceride levels (Boerwinkle et al. 1991).
A number of explanations for the lack of consistency among populations in the association between allelic variations of the apo $\mathrm{B}$ signal peptide and total cholesterol, LDL-cholesterol and apo B levels can be suggested. First of all, more genes can be involved in the determination of altered lipid metabolism. Interactions between these genes can differ between populations and also among different samples of the same population. Secondly, the effect of an allele may differ across various populations, because its phenotypic expression may be different in different environmental milieus. Interactions between genes and the environment may result in one allele being associated with the disease in one 
environment and other alleles of the same genes being associated with pathological symptoms in another environment. The mechanism explaining the association of Ins/Del polymorphism with plasma lipid variations is not yet well understood. Compared to the Ins allele, the Del allele is characterized by the absence of three amino acids (Leu-Ala-Leu), which could lead to alterations in the hydrophobicity of the signal peptide. Indeed, the deletion of the tripeptide in the hydrophobic part of the signal peptide affects in several in vitro models (Sturley et al. 1994, Benhizia et al. 2001, Plonné et al. 2001) the translocation of nascent apo B, its assembly with the lipids and its secretion in VLDL form, particulary in the presence of lipids (Benhizia et al. 2001). It has been shown in rats that an unfavorable assembly of VLDL is associated with a direct hepatic production of LDL (Plonné et al. 2001). This might happen in Del allele carriers. Another hypothesis concerns the possibility that, if assembly and secretion in VLDL are defective, lipids (including cholesterol) may accumulate in the cell and then provoke a decrease in the synthesis of LDLreceptors. It has been shown that the stimulation of assembly and secretion of VLDL is associated with an increase of the transcription of the LDL-receptor gene in a model of obese mice (Siri et al. 2001). Yet, the absence of a significant effect of the Ins/Del polymorphism on the plasma TG in our study could serve as an argument against both these hypotheses. Nevertheless, an effect of the Ins/Del polymorphism on the kinetics of the secretion of VLDL has already been found in the absence of a significant effect on plasma triglycerides (Riches et al. 1998, Watts et al. 2001). Finally, an indirect effect of the Ins/Del polymorphism by linkage disequilibrium with a functional polymorphism cannot be excluded.

In conclusion, we have found in this sample from the Tunisian population, that genetic variants in the signal peptide region of the apo $\mathrm{B}$ gene are associated with changes in LDL-cholesterol and apo B levels. Because the Del allele is associated with higher LDL-C and apo B levels, individuals carrying this allele may be at a higher risk of developing atherosclerosis.

\section{Acknowledgements}

This work was supported by grants from the "Ministère de la Recherche Scientifique, de la Technologie et du développement des Compétences" of Tunisia.

\section{References}

ANDERSON JL, BUNKER CH, ASTON CE, KAMBOH MI: Relationship of two apolipoprotein B polymorphisms with serum lipoprotein and lipid levels in African blacks. Hum Biol 69: 793-807, 1997.

AVOGARO P, BITTOLO BON G, GAZZOLATO G, QUINCI GB: Are lipoproteins better discriminators than lipids for atherosclerosis? Lancet 1: 901-903, 1979.

BENHIZIA F, GINSBERG HN, HUMPHRIES SE, TALMUD PJ: Variation in the human apoB signal peptide modulates apoB17 translocation. Biochem Biophys Res Commun 283: 149-157, 2001.

BOEKHOLDT SM, PETERS RJ, FOUNTOULAKI K, KASTELEIN JP, SIJBRANDS EJ: Molecular variation at apolipoprotein $\mathrm{B}$ gene locus in relation to lipids and cardiovascular disease: a systematic meta-analysis. Hum Genet 113: 417-425, 2003.

BOERWINKLE E, CHAN L: Three codon insertion/deletion polymorphism in the signal peptide region of the human apolipoprotein B (APO B) gene directly typed by the polymerase chain reaction. Nucleic Acids Res 17: 4003, 1989.

BOERWINKLE E, LEE SS, BUTLER R, SCHUMAKER VN, CHAN L: Rapid typing of apolipoprotein B DNA polymorphism by DNA amplification. Atherosclerosis 80: 225-232, 1990.

BOERWINKLE E, CHEN SH, VISVISKIS S, HANIS CL, SIEST G, CHAN L: Signal peptide length variation in human apolipoprotein B gene. Molecular characteristics and association with plasma glucose levels. Diabetes 40: 1539-1544, 1991.

BOHN M, BAKKEN A, ERIKSSON J, BERG, K: The apolipoprotein B signal peptide insertion deletion polymorphism is not associated with myocardial infarction in Norway. Clin Genet 45: 255-259, 1994.

BROWN MS, GOLDSTEIN JL: A receptor mediated pathway for cholesterol homeostasis. Science 232: 34-47, 1986.

CHOONG ML, KOAY ESC, KHAW MC, AW TC: Apoliporotein B 5'-Ins/del and 3'-VNTR polymorphisms in Chinese, Malay and Indian Singaporeans. Hum Hered 49: 31-40, 1999. 
FRIEDWALD WT, LEVY RI, FREDRICKSON DS: Estimation of the concentration of low-density lipoprotein cholesterol in plasma, without use of the preparative ultracentrifuge. Clin Chem 18: 499-502, 1972.

GAFFNEY D, FREEMAN DJ, SHEPHERD J, PACKARD CJ: The ins/del polymorphism in the signal peptide sequence of apolipoprotein B has no effect on lipid parameters. Clin Chim Acta 218: 131-138, 1993.

GAJRA B, CANDLISH JK, SAHA N: Influence of polymorphisms for apolipoprotein B (ins/del, XbaI, EcoRI) and apolipoprotein E on serum lipid and apolipoproteins in a Javanese population. Genet Epidemiol 11: 19-27, 1994.

GARDEMANN A, OHLY D, FINK M, KATZ N, TILLMANNS H, HEHRLEIN FW, HABERBOSCH W: Association of the insertion/deletion gene polymorphism of the apolipoprotein B signal peptide with myocardial infarction. Atherosclerosis 141: 167-175, 1998.

GLISIC S, PRLJIC J, RADOVANOVIC N, ALAVANTIC D: Study of apo B gene signal peptide insertion: deletion polymorphism in a healthy Serbian population: no association with serum lipid levels. Clin Chim Acta 263: 5765, 1997.

HANSEN PS, GERDES LU, KLAUSEN IC, GREGERSEN N, FAERGEMAN O: Polymorphisms in the apolipoprotein B-100 gene contributes to normal variation in plasma lipids in 464 Danish men born in 1948. Hum Genet 91: 45-50, 1993.

HIXSON JE, MCMAHAN A, MCGILL HC, STRONG JP: ApoB insertion/deletion polymorphisms are associated with atherosclerosis in young black but not young white males. Arterioscler Thromb 12: 1023-1029, 1992.

HONG SH, LEE CC, KIM JQ: Genetic variation of the apolipoprotein B gene in Korean patients with coronary artery disease. Mol Cells 7: 521-525, 1997.

HUBÁČEK JA, WATERWORTH DM, POLEDNE R, PIŤHA J, ŠKODOVÁ Z, HUMPHRIES SE, TALMUD PJ: Genetic determination of plasma lipids and insulin in the Czech population. Clin Biochem 34: 113-118, 2001.

JEMAA R, MEBAZAA A, FUMERON F: Apolipoprotein B signal peptide polymorphism and plasma LDL-cholesterol response to low-calorie diet. Int J Obes 28: 902-905, 2004a.

JEMAA R, MEBAZAA A, FUMERON F : Polymorphisme insertion/deletion du gène de l'apolipoprotéine B: effet sur les concentrations lipidiques chez les sujets obèses. Ann Biol Clin 62: 183-188, 2004b.

KAMMERER CM, VANDEBERG JL, HAFFNER SM, HIXON JE: Apolipoprotein B (apo B) signal peptide length polymorphisms are associated with apo B, low density lipoprotein cholesterol, and glucose levels in Mexican Americans. Atherosclerosis 120: 37-45, 1996.

MARCADET A, O'CONNEL P, COHEN D: Standardized southern blot workshop techniques. In: Histocompatibility Testing. DUPONT B (ed), Springer, New York, 1987, pp 587-590.

MARSHALL HW, MORRISON LC, WU LL, ANDERSON JL, CORNELI PS, STAUFFER DM, ALLEN A, KARAGOUNIS LA, WARD RH: Apolipoprotein polymorphisms fail to define risk of coronary artery disease. Results of a prospective angiographically controlled study. Circulation 89: 567-577, 1994.

OLOFSSON SO, BJURSELl G, BOSTROM K, CARLSSON P, ELOVSON J, PROTTER AA, REUBEN MA, BONDJERS G: Apolipoprotein B structure, biosynthesis and role in the lipoprotein assembly process. Atherosclerosis 68: 1-17, 1987.

PEACOCK R, DUNNING A, HUMSTEN A, TORNVALL P, HUMPHRIES S, TALMUD J P: Apolipoproten B gene polymorphisms, lipoproteins, and coronary atherosclerosis: a study of young myocardial infarction survivors and healthy population-based individuals. Atherosclerosis 92: 151-164, 1995.

PLONNÉ D, SCHULZE HP, KAHLERT U, MELTKE K, SEIDOLT H, BENNETT AJ, CARTWRIGHT IJ, HIGGINS JA, TILL U, DARGEL R: Postnatal development of hepatocellular apolipoprotein B assembly and secretion in the rat. J Lipid Res. 42: 1865-1878, 2001.

RENGES HH, WILE BD, MC KEIGNE MP: Apolipoprotein B gene polymorphisms are associated with lipid levels in men of South Asian descent. Atherosclerosis 91: 267-275, 1991.

RICHES FM, WATTS GF, VAN BOCKXMEER FM, HUA J, SONG S, HUMPHRIES SE, TALMUD PJ: Apolipoprotein B signal peptide and apolipoprotein E genotypes as determinants of the hepatic secretion of VLDL apoB in obese men. J Lipid Res 39: 1752-1758, 1998.

SAHA N, TAY JSH, CHEW CS: Influence of apolipoprotein B signal peptide insertion/deletion polymorphism on serum lipids and apolipoproteins in Chinese population. Clin Genet 41: 152-156, 1992. 
SAHA N, TAY JSH, HENG CK, HUMPHRIES SE: DNA polymorphisms of the apolipoprotein B gene are associated with obesity and serum lipids in healthy Indians in Singapore. Clin Genet 43: 113-120, 1993.

SIRI P, CANDELA N, ZHANG YL, KO C, EUSUFZAI S, GURSBERG HN, HUANG LS: Post-transcriptional stimulation of the assembly and secretion of triglyceride-rich apolipoprotein B lipoproteins in a mouse with selective deficiency of brown adipose tissue, obesity and insulin resistance. J Biol Chem 276: 46064-46072, 2001.

STURLEY SL, TALMUD PJ, BRASSEUR R, CULBERTSON MR, HUMPHRIES SE, ATTIE AD: Human apolipoprotein B signal sequence variants confer a secretion-defective phenotype when expressed in yeast. J Biol Chem 269: 21670-21675, 1994.

TURNER PR, TALMUD PJ, VISVISKIS S, EHNHOLM C, TIRET L: DNA polymorphisms of the apoprotein B gene are associated with altered plasma lipoprotein concentrations but not with perceived risk of cardiovascular disease: European Atherosclerosis Research Study. Atherosclerosis 116: 221-234, 1995.

VISVIKIS S, CAMBOU J P, ARVEILER D, EVANS AE, PARRA HJ, AGUILLON D, FRUCHART JC, SIEST G, CAMBIEN F: Apolipoprotein B signal peptide polymorphism in patients with myocardial infarction and controls. Hum Genet 90: 561-565, 1993.

WATTS GF, RICHES FM, HUMPHRIES SE, TALMUD PJ, VAN BOCKXMEER FM. Genotypic associations of the hepatic secretion of VLDL apolipoprotein B-100 in obesity. J Lipid Res 41: 481-488, 2001.

XU CF, TIKKANEN MJ, HUTTUNEN JK, PIETINEN P, BUTLER R, HUMPHRIES S, TALMUD PJ: Apolipoprotein B signal peptide insertion/deletion polymorphism is associated with Ag epitopes and involved in the determination of serum triglyceride levels. J Lipid Res 31: 1255-1261, 1990.

ZAMAN MM, IKEMOTO S, YOSHIIKE N, DATE C, YOKOYAMA T, TANAKA H: Association of apolipoprotein genetic polymorphisms with plasma cholesterol in a Japanese rural population. The Shibata Study. Arterioscler Thromb Vasc Biol 17: 3495-3504, 1997.

\section{Corresponding author}

R. Jemaa, Laboratoire de Biochimie, Hôpital la Rabta,1007, Jabbari, Tunis, Tunisie. Fax: +71 561 912. E-mail: jemaa_riadh@yahoo.fr 